\title{
Recent developments in urban marginality along Mexico's northern border
}

\author{
Sergio Peña* \\ Department of Political Science, University of Texas at El Paso, Benedict Hall 310, El Paso, TX 79968-0547, USA
}

Received 28 October 2002; received in revised form 7 April 2003; accepted 15 October 2003

\begin{abstract}
This paper analyzes recent developments in urban marginality along Mexico's northern border. The northern border in the last two decades has undergone a significant economic transformation as well as an explosive population growth. The paper emphasizes that in spite of impressive economic indicators border cities in Mexico urban marginality continue; that is, economic gains have not trickled down as it would be expected. Urban marginality is defined here based on access to basic public services such as water, sewer and electricity. A discussion of market failures and government failures is presented to evaluate to what extent or degree marginality can be attributed to one or the other. The main finding of this paper is that although there has been some quantitative improvement in delivery of services, access and distribution have been uneven; therefore, marginality among lower-income groups continues. The key conclusion in the paper points towards the need of strengthening and developing planning institutions that would give local governments the tools to manage urban growth such as asserting their eminent domain power to improve land markets and accessibility to poor people to formal housing; fiscal powers as well as professionalizing city managers.
\end{abstract}

(C) 2003 Elsevier Ltd. All rights reserved.

Keywords: Urban marginality; Disparities; Borders; Mexico

\section{Introduction}

The idea for this paper emerged from a simple question: What has been said about urban marginality in Mexico's northern border cities and what has changed in the last decade? The timing of the question is appropriate given the fact that data from the 2000 census in Mexico has been made available by the National Institute of Statistic and Geographical Information (INEGI,

\footnotetext{
*Tel.: + 1-915-747-8938; fax: + 1-915-747-6616.

E-mail address: spena2@utep.edu (S. Peña).
} 
2000), and this allows us to evaluate the changes in urban marginality in the last decade. The paper uses data from the Mexican 1990 and 1995 population censuses; it also reviews the previous work of authors such as Guillén (1990), and Pick and Butler (1990) as benchmarks to evaluate the changes in some marginality indicators.

Perhaps the most intriguing work on the topic of urban marginality along Mexico's northern border is that of Guillén (1990, p. 106), who found that in spite of very impressive economic indicators for border cities for such things as unemployment, salaries, and productivity these cities also presented high levels of marginality. Marginality in Guillén's work is conceptualized as access to basic utility services such as piped water, sewer and electricity. Another work on the subject by Pick and Butler (1990, p. 32) who defined it based on 19 indicators divided into six categories: economic, nutrition, education, health, housing and others such as access to electronic goods like TV and radio. Marginality as it is employed in this paper will be discussed more fully below in more detail.

The two works cited above agree on a key issue - which is that there exists a paradox between economic and urban development indicators. The paradox is that border cities, in spite of experiencing an economic boom since mid-1980s, also experience high levels of urban marginality understood as lack of access to key urban services that are important to people to improve their quality of life. The economic boom has not trickled down since people, although they are employed, earn relatively higher salaries, and have higher levels of productivity, have been marginalized from accessing basic urban amenities. This paper explores the validity of the paradox described and also analyzes the arguments concerning why the paradox continues or has been reversed. The main finding of this paper is that although there has been some quantitative improvement in delivery of services, their accessibility and distribution have been uneven; therefore, marginality among lower-income groups continues.

The paper is divided into five sections. The first section offers background about Mexico's northern border over the last three decades in order to help the reader situate the area in its proper historical and spatial context. The second section presents a conceptual framework to understand the meaning of urban marginality. The third section presents the methodology and a discussion of the main findings. The fourth section discusses the extent to which urban marginality is the result of market failures or government failures with respect to urban planning policies. The last section presents the conclusions related to policy implications regarding urban marginality.

\section{Changes on the US-Mexican border since 1970}

In recent decades, the US-Mexico border has experienced a dramatic change in every aspectsocial, political and economic. These changes are the result of two intertwined processes. On the one hand, the loss of competitiveness of the United States has resulted in the transformation of the production process from a fordist industrial organization into a flexible post-fordist model. A key feature of this model is the relocation of manufacturing to locations that offer cost savings in the production of labor-intensive products. The other process was Mexico's shift in its development model from an import-substitution strategy to an export-oriented model; the new model became an alternative to deal with the macroeconomic imbalances, such as the foreign debt 
problem faced by the country in 1982, and as a means of establishing a foundation for sustainable growth based upon neoliberal policies.

The combination of the above factors made the border an attractive place to relocate laborintensive production processes (for example, assembly lines) of industries that had lost their competitive advantage, such as the automotive, electronics, and apparel industries. The appeal of the border can be explained not only by its comparative advantage (abundant labor), which would reduce the labor costs of production, but also by its locational advantage or proximity to consumer markets in the United States, resulting in transportation cost savings. The structural differences and economic asymmetries between Mexico and the US have created opportunities that both countries, as recognized by signing the North American Free Trade Agreement (NAFTA) along with Canada, thereby creating one of the biggest free trade zones in the world with almost 400 million consumers.

Mexico has seen an expansion of assembly plants, known as maquiladoras, whose main function is basically to transform inputs brought mainly from the US into finished products. The maquiladora industries essentially operate as an economic enclave since Mexico benefits mainly through job creation and its corresponding payroll because there are very limited backward and forward linkages with the domestic industry. According to the Mexican National Institute of Statistical and Geographical Information (INEGI), the value added of manufactured goods by the maquiladora industry has become the country's main source of foreign exchange ( $\$ 8.1$ billion) followed by oil (\$7 billion), remittances from Mexicans abroad-mainly in the US (\$2.9 billion) and tourism (\$ 1.7 billion).

Until the 1980s, maquiladoras were only allowed to locate within the free zone of the Mexican border (see Fig. 1), which covers about $30 \mathrm{~km}$, but during the process of economic liberalization, maquiladoras were allowed to locate anywhere and sell part of their production to the domestic market. The geographic impact of the maquiladora industries, however, continues to be concentrated mainly along Mexico's northern border. Table 1 shows that in 2000, at the peak of the economic boom in the US, the number of plants reached 3703 and employed more than 1.3 million people. Almost one out of two maquildora plants were located in cities along the USMexico border. The cities of Tijuana and Ciudad Juárez concentrated about one-third of the plants and employment. Putting things into perspective, according to Lorey (1990, p. 329), in 1970 there were only 120 plants that employed 290,327 people. By 1980, the number reached 620 and employed 119,546. Only 11.3\% were located outside the border region. As we can see, the growth of the industry has been strong; the number of plants increased threefold in the decade from 1970 to 1980 and fivefold from 1980 to 2000 .

The growth of the maquiladora industry along Mexico's northern border went hand in hand with demographic changes. The population in border communities has increased exponentially since 1970 as well. For example, Tijuana quadrupled its population in 30 years from 277,306 in 1970 to $1,212,232$ in 2000. Ciudad Juarez tripled its population in 30 years from 407,370 in 1970 to $1,217,818$ in $2000 .{ }^{1}$ The population growth was mainly due to migration. In the last 30 years, one out of three residents of Ciudad Juarez and one out of two residents of Tijuana have migrated to the city.

\footnotetext{
${ }^{1}$ Data comes from Lorey (1993) and http://www.inegi.gob.mx/estadistica/espanol/economia/feconomia.html.
} 


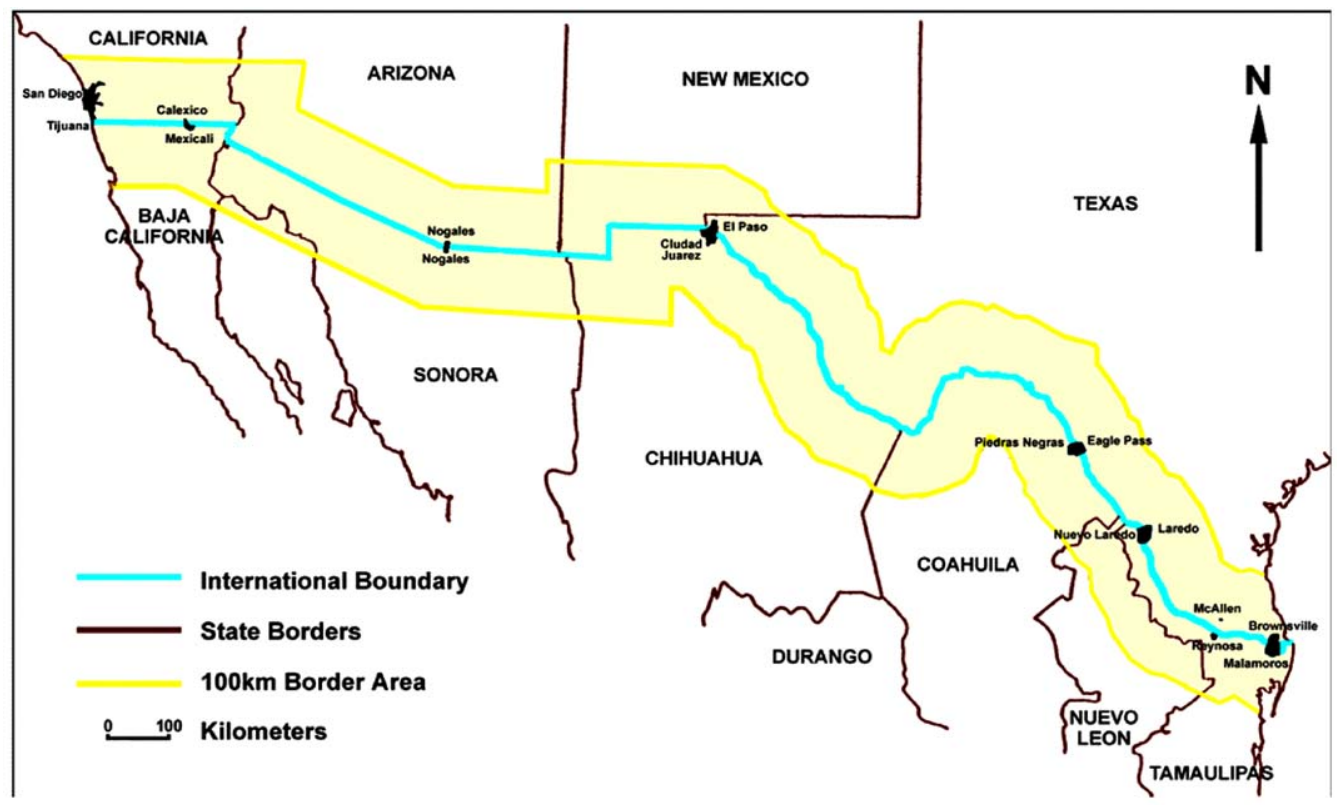

Source: Panamerican Health Organization

Fig. 1. US-Mexico border.

Table 1

Maquiladora plants and employment by city

\begin{tabular}{lcccc}
\hline Border cities & Number of plants & \% of all plants & Employment & \% employment by city \\
\hline Matamoros & 119 & 3 & 66,023 & 4.93 \\
Reynosa & 130 & 4 & 69,378 & 5.18 \\
Nuevo Laredo & 54 & 1 & 22,603 & 1.69 \\
Piedras Negras & 38 & 1 & 14,546 & 1.09 \\
Acuña & 56 & 2 & 32,130 & 2.40 \\
Ciudad Juárez & 308 & 8 & 249,509 & 18.63 \\
Tijuana & 779 & 21 & 184,756 & 13.80 \\
Other cities & 2219 & 60 & 700,045 & 52.28 \\
National 2000 & 3703 & & $1,338,990$ & 100.00 \\
National $1985^{\text {a }}$ & 785 & & 221,100 & \\
National $1980^{\text {a }}$ & 620 & & 119,546 & \\
National $1970^{\text {a }}$ & 120 & & 20,327 & \\
\hline
\end{tabular}

Source: INEGI (2000).

${ }^{\mathrm{a}}$ Data from Lorey (1990, p. 329).

According to Peach and Williams (2000), the age groups that experienced the largest percentage change in the 1990s were the 0-4 and the 15-64 age groups, with 25\% growth each. The authors conclude that these changes are related since people who move to the region for work (ages 15-64) 
either moved with their families or are in the reproductive age group starting new families and households.

An important issue that arises from the above analysis is how border cities have dealt with the pressure that these demographic changes impose on the demand of housing as well as public services such as drinking water, sewer, and roads. According to Peach and Williams (2000, p. 40), in 1980 the Mexican border communities had a total population of 2.9 million and by 1995 the total population reached 4.7 million. This means that local governments in the border cities had to accommodate nearly 2 million new residents.

Furthermore, it is important to keep in mind that during those years, Mexico suffered one of its most severe economic disasters. The nation was almost bankrupt and the Federal Government was struggling to put its public finances back in order by cutting government spending, removing subsidies, and collecting more taxes to comply with the structural adjustment programs negotiated with the International Monetary Fund in exchange for more loans and debt relief.

In summary, border cities had to accommodate a very large migration wave to the north with resulting demands for urban amenities and public services at a time of limited resources given that the Federal Government was unable to increase public spending. Furthermore, in 1983, Article 115-III of the Mexican Constitution was modified and basically the Federal Government transferred the burden of public services and utilities to local governments. The outcome of these public policies will be analyzed below. The paper will analyze the dimension of the problem by looking at data regarding access to public services such as drinking water, sewer, and electricity. However, before presenting the results it is important to discuss the concept of urban marginality that is used in this study.

\section{Urban marginality}

This paper, as stated before, has the objective of analyzing what has changed regarding urban marginality along Mexico's northern border and the works by Guillén (1990) and Pick and Butler (1990) are used as benchmarks. Both articles used the concept of urban marginality in the same way as the National Council of Population in México (CONAPO). For comparative purposes, this article also uses the same definition as CONAPO, which identifies urban marginality as a social problem associated with the lack of opportunities and access by the population to services such as education, health, and income as well as urban amenities such as drinking water, sewer, and electricity which are used in this paper to compare and assess the changes in the degree of urban marginality. Furthermore, this analysis differentiates between two types of marginalityinter- and intra-urban marginality. The former refers to a comparison of marginality across units of analysis, whereas the latter refers to marginality within the same unit of analysis. The units of analysis used here are states and municipalities as defined by the political system in México.

\subsection{The neoclassical approaches to urban marginality}

The neoclassical theory of labor economics states that wages are a reflection of worker productivity or the wage is equal to the marginal product of the worker (Ehrenberg \& Smith, 2000). Furthermore, the labor supply theory states that a worker allocates his time to perform two 
activities - work and leisure - and the amount of time the worker allocates to work reflects his preference for acquiring a bundle of goods and services (Pencavel, 1986). Thus, the purchase or access to a bundle of goods and public services will be related to the worker's income. At the same time, income is a reflection or function of the worker's marginal productivity. Other things being equal, this suggests that regions with higher productivity would also pay higher wages and people would be able to purchase or have access to urban services.

One assumption made by the neoclassical theory is that governments and markets operate in equilibrium and there are no market failures in the form of monopolies, externalities, asymmetric information, and public goods. One argument for government intervention is to correct market failures (Levy, 1995, pp. 79-91) in which several public services fall in the category of natural monopolies. ${ }^{2}$ However, public choice theory drawing from the arguments put forward by Samuelson and Tiebout states that government can also be a source of failures (Heikkila, 2000; Holcombe, 1983). A government failure is defined as a situation where government is unable to provide public goods that are part of its domain or where it has the monopoly, such as law and order. This discussion suggests two hypotheses:

(1) If market failures are minimal there should be a negative correlation between income and urban marginality. That is, income will be a good measure of urban marginality.

(2) If income is not a good measure of urban marginality, that is, that in spite of higher income there exists a large degree of marginality, then urban marginality will be the result of government rather than market failures.

\subsection{Inter-state marginality}

Interurban marginality compares the marginality among states to see the relationship between income and marginality. As stated before, it is expected that states with higher incomes (and productivity) will have lower marginality. According to a study by the National Population Council (CONAPO) in Mexico, there is a close negative relationship between productivity and marginality. In other words, the most productive states should have the lowest marginality. Applying a simple linear regression to data from CONAPO, where the independent variable is the natural logarithm of the GDP per capita and the dependent variable the marginality index ${ }^{3}$ developed by CONAPO, the results ${ }^{4}$ show that $64.4 \%$ of the variability of the marginality index of CONAPO is explained by the productivity factor (GDP per capita, Fig. 2).

Overall, the northern border states (Baja California, Chihuahua, Sonora, Tamaulipas, Nuevo Leon, and Coahuila) have negative unstandardized residuals, which means that their marginality level is lower than the adjusted value given the level of GDP per capita. On the other hand, states in the southern region of México have positive unstandardized residuals, which means that their

\footnotetext{
${ }^{2} \mathrm{~A}$ natural monopoly is said to exist when it is more efficient to have only one supplier as opposed to having competition among several suppliers.

${ }^{3}$ The index considers four structural dimensions of marginality (1) education, housing, income, and population distribution. These dimensions are used to measure exclusion or lack of access by the population to services related to the four dimensions mentioned previously, http://www.conapo.gob.mx/publicaciones/indices/pdfs/001.pdf.

$\begin{array}{ccccccc}\text { Dependent Mth } & \text { Rsq } & \text { d.f. } & F & \text { Sigf } & b 0 & b 1 \\ \text { MARGINALITY INDEX LIN } & 644 & 30 & 54.29 & 0.000 & 171.335 & -17.185\end{array}$.
}




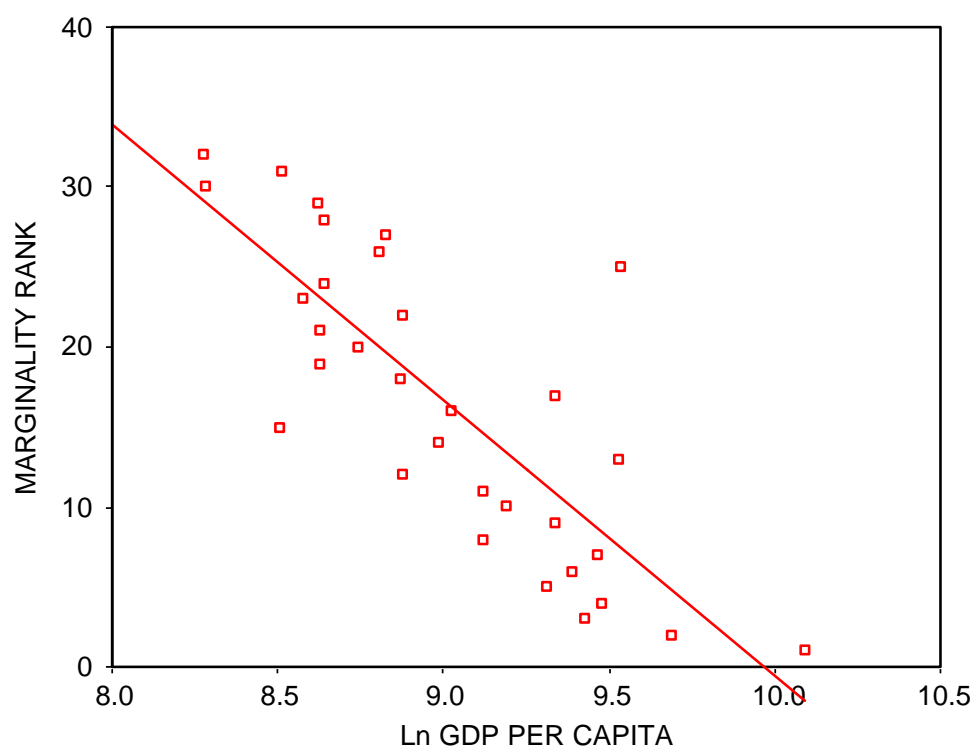

Fig. 2. Marginality index and GDP per capita.

marginality level is above the adjusted value. The data in the above graph shows two states that do not fit to the adjusted pattern. One is the southern Mexican state of Campeche which has a high GDP per capita but also shows a high degree of marginality. This is because the wealth of Campeche is based on the oil industry, which is a state-owned enterprise, and while it provides good-paying jobs, the economic base of the state is otherwise poorly diversified and heavily dependent on primary activities. The opposite case is the state of Tlaxcala in central Mexico, which, in spite of having low productivity, also displays a low degree of marginality. A reason for this is that the state is small and close to two important industrial production centers, Puebla and Mexico City, where the population commutes to work or benefits (see Table 2).

The above results, however, can be misleading because they only compare states and do not analyze the intra-municipal or intra-urban marginality. The data presented by CONAPO is aggregated and does not allow analysis of marginality at a lower scale within a city nor of how spatial and income segregation are related to marginality. The conclusion in this CONAPO study appears to be that neither market failures nor government failures exist and that therefore municipalities in the border states are doing fine compared to some other states in the south, such as Campeche and Chiapas.

However, it is obvious that in northern border cities, in spite of higher levels of productivity, there exists a high degree of marginality of segments of the population that do not have access to basic services. In summary, an analysis of inter-urban marginality hides the real urban problems associated with market and government failures. Therefore, it is important to perform a more disaggregated analysis at the intra-urban level to have a better idea of the size of the problem of urban marginality. 
Table 2

Productivity and Marginality

\begin{tabular}{|c|c|c|c|c|}
\hline \multirow[t]{2}{*}{ State } & \multirow[t]{2}{*}{ GDP $\mathrm{P} / \mathrm{C}$} & \multirow[t]{2}{*}{ Marginality rank } & \multicolumn{2}{|c|}{ Unstandardized } \\
\hline & & & Residual & Region \\
\hline Nuevo Leon & 16,118 & 2 & -2.85 & Border \\
\hline Chihuahua & 12,895 & 7 & -1.68 & Border \\
\hline Baja California & 12,434 & 3 & -6.31 & Border \\
\hline Sonora & 11,334 & 9 & -1.9 & Border \\
\hline Tamaulipas & 9808 & 10 & -3.39 & Border \\
\hline Coahuila & 13,072 & 4 & -4.45 & Border \\
\hline Campeche & 13,820 & 25 & 17.51 & South \\
\hline Quintana Roo & 13,744 & 13 & 5.41 & South \\
\hline Yucatan & 7136 & 22 & 3.15 & South \\
\hline Morelos & 7958 & 14 & -2.98 & South \\
\hline Tabasco & 5655 & 24 & 1.15 & South \\
\hline Chiapas & 3936 & 32 & 2.92 & South \\
\hline Veracruz & 5546 & 29 & 5.82 & South \\
\hline Oaxaca & 3946 & 30 & 0.97 & South \\
\hline Guerrero & 4973 & 31 & 5.94 & South \\
\hline Baja California Sur & 11,929 & 6 & -4.02 & North \\
\hline Aguas Calientes & 11,028 & 5 & -6.37 & North \\
\hline Durango & 8281 & 16 & -0.3 & North \\
\hline Sinaloa & 7090 & 18 & -0.96 & North \\
\hline San Luis Potosi & 6802 & 27 & 7.32 & North \\
\hline Zacatecas & 5574 & 21 & -2.1 & North \\
\hline Nayarit & 5580 & 19 & -4.08 & North \\
\hline Queretaro & 11,378 & 17 & 6.16 & Central \\
\hline Colima & 9150 & 11 & -3.58 & Central \\
\hline Jalisco & 9120 & 8 & -6.64 & Central \\
\hline Morelos & 7958 & 14 & -2.98 & Central \\
\hline Mexico & 7178 & 12 & -6.75 & Central \\
\hline Puebla & 6675 & 26 & 6 & Central \\
\hline Guanajuato & 6272 & 20 & -1.07 & Central \\
\hline Hidalgo & 5660 & 28 & 5.17 & Central \\
\hline Michoacan & 5316 & 23 & -0.91 & Central \\
\hline D.F. & 24,059 & 1 & 3.03 & Central \\
\hline Tlaxacala & 4933 & 15 & -10.2 & Central \\
\hline
\end{tabular}

Source: Adapted from CONAPO (2000).

\section{Intra- and inter-urban marginality along the northern Mexican border}

This section analyzes inter- and intra-urban marginality for nine Mexican border cities. The study uses three variables to assess the level of marginality - whether the house has indoor piped water, electricity, and is connected to the municipal sewer service. These variables were chosen to compare the changes in urban marginality during the decade from 1990 to 2000. In this study, intra-urban marginality is evaluated based on access to the services mentioned above by different socioeconomic groups. The four socioeconomic groups were categorized based on quartiles of 
household total income using the 2000 census data where Quartile I represents the lowest income grouping and the Quartile IV the highest. The study uses census data from 1990, 1995 and 2000 in order to assess the changes at the aggregate level.

The study uses the case of Ciudad Juarez to show how urban marginality is concentrated in some areas of the city, creating a spatial segregation of poverty. That is, poverty is concentrated in pockets and areas instead of being dispersed or randomly located through out the entire city.

\subsection{Sewers}

Table 3 shows access to sewer services in nine of the largest border cities. In general, the 2000 census shows that three out of four households $(75.0 \%)$ in the border cities are connected to the city's sewer system, an improvement with respect to the 1990 census which reported approximately two of four households $(58.5 \%)$ were connected to the sewer system. In general, the 2000 census shows that the border municipalities are better off than the national average of $60.9 \%$ with regard to access to sewers.

Table 3 also shows that access to sewer service is positively correlated to economic status. For instance, on average $63.9 \%$ of the households in the lowest stratum (I) are connected to the sewer compared with $86.8 \%$ in the highest stratum (IV). The differences between the income groups are statistically significant at the alpha level (0.05) as revealed by paired $t$-tests (see Appendix A). Comparing this at the national level, the percentage of homes with access to sewer services suggests that the lowest stratum in the border cities is slightly better off than the national average.

However, contrasting the difference within groups and looking at accessibility by level of income within the same municipalities, the story is completely different. At the lowest stratum (I), the biggest difference (36.2 percentage points) is between Nuevo Laredo and Ciudad Acuña. Among poor people, the residents of Laredo are far better off that those in Ciudad Acuña. In Nuevo Laredo about 4 out of 5 of the poorest residents have access to the sewer service compared to approximately 2 out of 5 in Ciudad Acuña and 3 out of five at the national level. Overall, in the

Table 3

Access to sewer by income groups and cities (\%)

\begin{tabular}{llllllrrr}
\hline & I & II & III & IV & 2000 & \multicolumn{1}{c}{1995} & 1990 \\
\hline Tijuana & 67.2 & 67.0 & 71.5 & 84.4 & 75.5 & 65.4 & 55.2 & 20.3 \\
Mexicali & 53.2 & 60.5 & 71.1 & 81.5 & 69.7 & 67.2 & 60.9 & 8.8 \\
Piedras Negras & 73.5 & 73.4 & 77.9 & 92.0 & 79.2 & 68.7 & 60.2 & 19.0 \\
Ciudad Acuña & 43.9 & 55.4 & 62.0 & 78.6 & 60.1 & 47.6 & 38.3 & 21.8 \\
Ciudad Juárez & 79.3 & 85.7 & 89.4 & 94.2 & 88.3 & 85.3 & 66.9 & 21.4 \\
Nogales & 74.0 & 75.0 & 81.4 & 89.1 & 81.1 & 80.9 & 69.8 & 11.3 \\
Matamoros & 52.2 & 65.9 & 71.7 & 86.0 & 68.6 & 61.5 & 52.9 & 15.7 \\
Nuevo Laredo & 80.1 & 82.4 & 88.7 & 93.1 & 86.3 & 77.9 & 72.1 & 14.2 \\
Reynosa & 52.1 & 60.0 & 67.3 & 82.6 & 66.3 & 59.6 & 50.3 & 16.0 \\
Border cities & 63.9 & 63.4 & 75.6 & 86.8 & 75.0 & 68.3 & 58.5 & 16.5 \\
\hline
\end{tabular}

Source: INEGI Census (2000), 1995 population counting, and 1990 census.

$\Delta=$ Change [1990-2000]. 
border cities, the highest income group is 1.2 times more likely to be connected to the sewer system than the lowest income group.

Among the highest income group (IV) the biggest difference (15.6 percentage points) is between Ciudad Juarez and Ciudad Acuña. Ciudad Acuña continues being an interesting case because it has the biggest improvement (21.8\%) from 1990 to 2000 but still lags behind the rest of the border cities. In summary, among the wealthy households the ones in Ciudad Juárez have better access to sewer services compared to other wealthy people in the other border towns.

CONAPO concluded that the state of Coahuila, where Ciudad Acuña is located, has a low level of marginality. However, the above data suggests that at the intra-level, the municipality of Ciudad Acuña in Coahuila presents a high degree of marginality. The same is true for other border states in that the CONAPO index shows low levels of marginality but looking at the data at the inter-municipal and intra-municipal levels, the border cities still continue presenting a severe gap of access to sewer services.

\subsection{Piped water}

Table 4 presents the results of households with access to piped water inside the home. This service is among those that present the most variability. At the national level, it was reported that $63.5 \%$ of the households have access to this service. In the border region, the percentage of households with piped water inside the home improved almost 15 percentage points from 1990 to 2000. The border region also presents better coverage with $74 \%$ compared to $63.5 \%$ nationally.

Inter-municipal comparisons show that the cities of Piedras Negras, Ciudad Acuña, Mexicali, Matamoros and Tijuana are the ones that experienced the greatest improvement from 1990 to 2000 , exceeding the average of $14.9 \%$ for the region. On the other hand, Nuevo Laredo and Nogales are the worst performers in this area. Nogales for practical purposes did not show any relative improvement.

The results across income groups present the same pattern as with the sewer service, that is, the higher the income the higher the probability that the household will have access to piped water.

Table 4

Piped water inside home by income group (\%)

\begin{tabular}{|c|c|c|c|c|c|c|c|c|}
\hline & I & II & III & IV & 2000 & 1995 & 1990 & $\Delta$ \\
\hline Tijuana & 64.9 & 64.4 & 68.8 & 84.0 & 73.8 & 68.8 & 55.6 & 18.2 \\
\hline Mexicali & 69.2 & 73.3 & 82.5 & 90.7 & 81.4 & 76.3 & 63.8 & 17.6 \\
\hline Piedras Negras & 77.8 & 82.7 & 85.1 & 96.4 & 85.5 & 78.5 & 65.9 & 19.6 \\
\hline Ciudad Acuña & 51.9 & 64.1 & 72.8 & 85.7 & 68.9 & 71.6 & 50.2 & 18.7 \\
\hline Ciudad Juárez & 67.2 & 74.1 & 81.7 & 91.0 & 80.3 & 80.2 & 64.9 & 15.4 \\
\hline Nogales & 52.3 & 54.8 & 66.4 & 78.1 & 65.0 & 76.5 & 65.6 & -0.6 \\
\hline Matamoros & 43.7 & 55.2 & 62.2 & 81.4 & 60.2 & 56.8 & 43.2 & 17.0 \\
\hline Nuevo Laredo & 67.8 & 67.1 & 78.0 & 87.9 & 75.6 & 73.1 & 66.8 & 8.8 \\
\hline Reynosa & 54.9 & 61.8 & 74.8 & 88.8 & 70.9 & 69.4 & 55.7 & 15.2 \\
\hline Border cities & 62.0 & 66.4 & 74.7 & 87.1 & 74.0 & 72.3 & 59.1 & 14.9 \\
\hline
\end{tabular}

Source: INEGI Census (2000), 1995 population counting, and 1990 census.

$\Delta=$ Change [1990-2000]. 
From the three services used as indicators of urban marginality, access to piped water presents the biggest dispersion of accessibility between the lowest and the highest income groups; that is, the highest income group is 1.4 times more likely to have piped water inside the home compared with the lowest income group. The $t$-test performed on the different combination of pairs resulted in statistical significance at the alpha level (0.05). Of all the variables used, access to piped water inside the home presents the highest variation among the different income groups.

There also exist significant differences within the same income stratum. The difference in the lowest stratum (I) is about 34.1 percentage points between the city with the lowest score (Matamoros, 43.7\%) and that with the highest score (Piedras Negras, 77.8\%). In the lowest quartile, the cities of Reynosa, Matamoros, Nogales, and Ciudad Acuña performed below the border average for that specific income group. On the other hand, the difference within the highest quartile is much smaller (12.4 percentage points) compared to the lowest quartile (34.1 percentage points). The municipalities that present the biggest difference within the highest income group are Piedras Negras (96.4\%) and Nogales $(78.1 \%)$.

\subsection{Electricity}

Table 5 shows the results for access to electricity. Border cities or municipalities had slightly better access $(96.6 \%)$ than the national average $(95 \%)$. In general, it can be concluded that this service is the most ubiquitous of all given that the differences are less significant between municipalities and income groups. Electricity coverage in the border cities increased by 9.5 percentage points from 1990 to 2000 and access to this service is becoming almost universal, approaching 100\% coverage for urban areas in the border.

Looking at all the border municipalities, Reynosa, Matamoros, and Tijuana are the ones that experienced the biggest improvement in this service given that in 1990 they were the ones with the lowest percentage but approached the average by 2000. Borderwide, the gap in accessibility to electricity between the lowest and the highest income groups is the smallest compared with sewer and piped water and the odds (1.05) are nearly one which means that all income groups are as

Table 5

Access to electricity by income group (\%)

\begin{tabular}{|c|c|c|c|c|c|c|c|c|}
\hline & I & II & III & IV & 2000 & 1995 & 1990 & $\Delta$ \\
\hline Tijuana & 94.0 & 95.5 & 96.7 & 98.5 & 96.9 & 95.0 & 83.3 & 13.6 \\
\hline Mexicali & 94.9 & 97.5 & 98.6 & 98.3 & 97.6 & 97.9 & 93.6 & 4.0 \\
\hline Piedras Negras & 97.0 & 98.6 & 99.0 & 99.7 & 98.6 & 96.9 & 94.6 & 4.0 \\
\hline Ciudad Acuña & 88.3 & 95.5 & 98.2 & 99.6 & 95.5 & 92.8 & 86.3 & 9.2 \\
\hline Ciudad Juárez & 95.2 & 98.0 & 98.5 & 98.6 & 97.8 & 98.3 & 91.1 & 6.7 \\
\hline Nogales & 89.1 & 91.9 & 95.3 & 97.5 & 94.2 & 92.1 & 83.9 & 10.3 \\
\hline Matamoros & 90.7 & 96.0 & 97.3 & 98.7 & 95.6 & 91.7 & 82.0 & 13.6 \\
\hline Nuevo Laredo & 97.3 & 97.4 & 98.5 & 99.2 & 98.1 & 94.6 & 89.5 & 8.6 \\
\hline Reynosa & 94.2 & 96.3 & 98.0 & 98.6 & 96.8 & 87.5 & 81.8 & 15.0 \\
\hline Border cities & 93.4 & 96.3 & 97.8 & 98.7 & 96.8 & 94.1 & 87.3 & 9.5 \\
\hline
\end{tabular}

Source: INEGI Census (2000), 1995 population counting, and 1990 census.

$\Delta=$ Change [1990-2000]. 
likely to have access to electricity. However, the difference continues to be statistically significant at the 0.05 significance level.

The difference within groups is smaller. In the lowest income group the biggest difference is just 9 percentage points between Nuevo Laredo and Ciudad Acuña. The difference within the highest income group is even smaller (2.2 percentage points) between Piedras Negras and Nogales. The biggest difference between quartiles I and IV in the same city is found in Ciudad Acuña $(11.3 \%)$, Nogales $(8.4 \%)$ and Matamoros $(8 \%)$.

So far, the data shows that the biggest dispersion of public service coverage is found in access to sewers and drinking water whereas the smallest variation is found in electricity. This suggests that access to electricity is perhaps the most fundamental and basic service which the population gets access to first. Drinking water becomes second in terms of priority and sewers are ranked third. It is important to emphasize that among all the public services perhaps these three are most fundamental for the survival of people and as a way of making their lives better.

Although electricity is the most universal service, sewers and piped water did show a greater dispersion not only between groups of cities but also among households of the same socioeconomic group. The following question emerged: Why does access to electricity present smaller differences and why are there larger differences in coverage of other services? This question is analyzed in the following section.

\section{Market and government failures}

It was pointed out above that comparisons across states hid market failures as well as government failures given the fact that the variation in marginality was explained to a great extent by income. This paper looked at the relationship between income and access to public services at a more disaggregated level or within municipalities and found the same development paradox as Guillén (1990), and Pick and Butler (1990), that is, although the border cities or municipalities have the best economic indicators of productivity, within the municipalities there exist levels of marginality that are not much better than the national average. The reason for this paradox is a combination of market as well as government failures related to the delivery of public services, land tenure, and access to affordable housing.

The delivery of sewer services, drinking water and electricity are examples of what economists call natural monopolies where it is more efficient to have only one supplier instead of several firms competing (Levy, 1995). The existence of externalities, public goods, and natural monopolies are used as an argument for government intervention in the delivery and supply of public services (Holcombe, 1996). The Government of Mexico uses this as a justification for intervention.

Several studies have pointed out the inefficiencies of government as a supplier of public services not only in Mexico but also across the world (Montesillos-Cedillo, 2000; Ostrom, Schroeder, \& Wynne, 1993; Serageldin, 1994; World Bank, 1997; Peña and Córdova, 2001). Among the key arguments the different authors have pointed out are the difficulty of pricing public services, such as water, and the unwillingness of governments to appropriately price the services because too frequently delivery of services has become politicized by political parties who use it to gain voter support across the social spectrum. For instance, political parties promise access to the poor and 
to keep subsidizing the consumption of public services of middle and upper income groups (Treviño, 1999).

The Mexican political system epitomized the above situation and contributed to a great extent in promoting market failures in the supply of public services. The existence of a dominant party, such as the Revolutionary Institutional Party (PRI), and a corporatist state, used the delivery of public services as a way to keep political control and the status quo of the country. However, this system began to erode as the capacity to finance public services by the Federal Government in the 1980s was hampered by the foreign debt crisis.

During the 1980s, the border municipalities experienced a massive influx of people seeking to fill job opportunities created by the opening of the country to foreign investment and trade and the arrival of maquiladoras in the region. Furthermore, due to changes to Article 115 of the Mexican Constitution, the burden of financing public services was transferred to local governments which were overwhelmed by the demand created by the migration of workers, expanding the gap in access to public services during the 1980s. The writings of Guillén (1990) and Pick and Butler (1990) focus on this period in which marginality increased substantially in the border region.

Although, as has been seen above, between 1990 and 2000, border municipalities have made big improvements in the provision of public services, narrowing the gap, they have not totally eliminated the marginality problem. Two factors explain this: the reactivation of Federal spending and the creation of new institutions as a result of NAFTA. The reactivation of Federal social spending during the period of President Carlos Salinas de Gortari (1988-1994) was financed in part by the economic boom that the country experienced and revenue generated from the sale of state enterprises which were uses in part to finance Federal programs, such as Programa Nacional de Solidaridad, developed to provide infrastructure in poor communities and to regain the political clout that the PRI had been losing during the 1980s (Mendez, 1995). In addition, Mexico and the United States signed a NAFTA side agreement to mitigate environmental impacts along the border, creating the Border Environment Cooperation Commission (BECC) and the North American Development Bank (NADB), giving border communities access to technical knowledge and financial resources. ${ }^{5}$

Land tenure and access to affordable housing is another dimension where market and government failures reflect and relate to access to public services by marginal populations. Different authors have documented extensively the difficulties poor people in developing countries face to access formal housing (De Soto, 1989; Ward, 1991; Duhau, 1998). Marginal populations in developing countries have solved their housing and public services problem informally or outside the formal legal system by squatting on available land, "stealing" electricity and buying public services such as water, solid waste collection, transport from informal vendors at higher prices, or what De Soto (1989) calls the cost of informality and access.

The above problem can be described as a typical example of government failure of law as well as a problem of market failure in the form of monopolizing land. The case of the border

\footnotetext{
${ }^{5}$ The types of projects supported by BECC are related to water supply, wastewater treatment, solid waste and other improvement projects along the United States-Mexico border. Recently, BECC's mandate was expanded to include projects that improve air quality, public transportation, clean and efficient energy, municipal planning and development and water management. BECC provides the technical knowledge certifying projects and NADB the financing, http://www.cocef.org/englishbecc.html.
} 
municipality of Ciudad Juarez epitomizes this issue. The land market in the city is controlled by a few developers who prefer to speculate, building industrial parks, and housing for middle- and upper-income groups that the majority of maquiladora workers would not be able to afford. The collusion between governments and developers is also present; as governments reward developers who support them by building infrastructure so developers can obtain immediate windfall gains as a result of public investment (Llera, 2003).

As the interests of government and developers are closely inter-related, the exercise of eminent domain is used in a very discretionary way. Eminent domain is perhaps the most powerful policy tool that governments have to manage the urban development process. Eminent domain is the ability of governments to take away land to advance the public interest. Eminent domain can break monopolies and make land available for affordable housing for the poor. The gains made by Ciudad Juarez and Tijuana during the 1990s are in part the result of policies implemented by the governments of the opposition party, the National Action Party (PAN), which won state and local elections and began programs to break the PRI's corporatist style of delivering services. The PAN made use of eminent domain powers and was reluctant to tolerate squatting (Padilla, 1995; Guillén, 2000).

In Ciudad Juárez, it is clear that the areas with the highest degree of marginality are located on the outskirts of the city (see map 2). The process of urbanization of the area to the west started as squatter settlements beginning in the 1970s and which were compounded during the 1980s. The east side of the city, also with a high degree of marginality, responded to a very different process. In recent years agricultural land collectively owned by ejidatarios ${ }^{6}$ has been subdivided and illegally transformed to urban land without regard or conforming to the urban development plan of the municipality. As a result these subdivisions lack the most basic services such as water, sewers and electricity.

\section{Conclusions}

The emergence of democracy at all levels of government along with the reevaluation of the role of governments in Mexico has created a debate concerning what is the best way or policy to address urban marginality. The border municipalities face the dilemma of how to ensure that the benefits of free trade trickle down to the population with the most pressing needs. The results presented here show that although border communities in the aggregate have made substantial improvements in regard to access to basic public services during the $1990 \mathrm{~s}$, there is still a substantial amount of work to overcome the development paradox described above.

The new scheme, or policy, to deliver public services and reduce urban marginality needs to address the issues of market and government failures.

A necessary but not sufficient condition is to ensure that law and order, as a basic government function, works to break monopolies in the land market by reasserting the eminent domain power that the Mexican Constitution grants to governments in Article 27. Thus would help guarantee

\footnotetext{
${ }^{6}$ The ejidatario is a member or stakeholder of an ejido. An ejido is a form of collective land tenure that has its historical roots in prehispanic times and was reenacted in Article 27 of the 1917 Constitution produced by the Mexican revolution. In 1987, the government of Salinas de Gortari passed a constitutional reform which lifted legal restrictions, thereby allowing ejidos land to be bought and sold.
} 
formal access to housing to low income people. The reassertion of the eminent domain power by governments needs to go hand in hand with a functional and efficient judicial system that would place limits to the public and private actions. This would make the planning process of urban development more institutionalized and eradicate the clientelist practices of the past where political parties used urban development as an electoral tool. For instance, Peña (2002) compares the institutional framework of urban development between Mexico and the US and arrives at the conclusion that the weakness of the institutions in Mexico to a great extent has contributed to informal housing. Authors such as Sim, Sau-Kim, and Lai-Choe (2002) have analyzed the housing market in Singapore and had arrived at similar conclusions that a strong government and an efficient institutional framework had been able to deter informal housing.

Also, it is important to professionalize the management of public utilities with the objectives of making them more efficient, equitable and environmentally sustainable. Different studies (Serageldin, 1994) about Mexico have shown that public utilities such as water do not cover their operating costs and require subsidies. This policy of subsidizing public utilities is inequitable given the fact that poor people pay a higher price for access to some public services as explained previously. The beneficiaries of the subsidies are middle and upper income people. Furthermore, there is a transfer of wealth from the poor to middle and upper classes in the case of border communities because, unlike some other regions, people in the poor areas work in formal jobs created by the maquiladoras and pay income tax to the Federal Government. However, the corresponding benefits in social and public services do not match their tax contributions. In summary, a policy of appropriately pricing the public services based on the principle that the one who consumes more pays more would help provide public utilities with the resources to maintain the system and investment to keep up with demand. As today there are very few cities in Mexico that have a metered system for water, most pay a flat fee. The fundamental challenge to this policy is to take public services from the political arena and partisan politics and bring them into the economics debate of how to price services and make subsidies more efficient and equitable to ensure that the poor are not priced out (Peña and Córdova, 2001).

Finally, the transfer of responsibility for supplying public services, such as water and sewers, from Federal to local government was not in tandem with fiscal tools. Local governments to a great extent still depend on Federal transfers accounting for more than half of the municipalities' revenue (Massolo, 1995). The main sources of local government revenue are the property tax, licenses, and permits. So, it is important to implement changes in the fiscal pact among all levels of government. Fiscal reform needs to give more fiscal powers to local governments so that they can manage the urban development process to, among other responsibilities, promote or restrict growth, to affect the location of growth, to negotiate the fiscal burden between developers and municipalities and to be able to issue debt or development bonds. Along the border there are binational metropolitan areas such as Tijuana-San Diego and El Paso-Ciudad Juarez that together would become among the largest cities in Mexico as well as in the US. However, crossborder planning has been overlooked by both Federal Governments and local municipalities had very limited power to engage and implement binational planning projects. Then, it is important also to continue fostering binational planning efforts and institutions such as BECC and NADB which has provided local governments with access to fund to continue improving living conditions in the border cities. 


\section{Appendix A}

The differences between the income groups are statistically significant at the alpha level $(0.05)$ as revealed by paired $t$-tests (see Table 6).

Table 6

$t$-test by stratum, paired samples test

\begin{tabular}{|c|c|c|c|c|c|c|c|c|}
\hline & \multicolumn{5}{|c|}{ Paired differences } & \multirow[t]{3}{*}{$t$} & \multirow[t]{3}{*}{$\mathrm{df}$} & \multirow{3}{*}{$\begin{array}{l}\text { Sig. } \\
\text { (2-tailed) }\end{array}$} \\
\hline & \multirow[t]{2}{*}{ Mean } & \multirow{2}{*}{$\begin{array}{l}\text { Std. } \\
\text { deviation }\end{array}$} & \multirow{2}{*}{$\begin{array}{l}\text { Std. } \\
\text { error mean }\end{array}$} & \multicolumn{2}{|c|}{$95 \%$ confidence interval of the difference } & & & \\
\hline & & & & Lower & Upper & & & \\
\hline \multicolumn{9}{|l|}{ Sewer } \\
\hline Pair 1 II-I & 5.5333 & 5.0914 & 1.6971 & 1.6197 & 9.4469 & 3.260 & 8 & 0.012 \\
\hline Pair 2 I-III & -11.7222 & 6.0332 & 2.0111 & -16.3597 & -7.0847 & -5.829 & 8 & 0.000 \\
\hline Pair 3 I-IV & -22.8889 & 8.8011 & 2.9337 & -29.6540 & -16.1238 & -7.802 & 8 & 0.000 \\
\hline Pair 4 II-III & -6.1889 & 2.0301 & 0.6767 & -7.7493 & -4.6285 & -9.146 & 8 & 0.000 \\
\hline Pair 5 II-IV & -17.3556 & 5.2123 & 1.7374 & -21.3621 & -13.3490 & -9.989 & 8 & 0.000 \\
\hline Pair 6 III-IV & -11.1667 & 4.5684 & 1.5228 & -14.6782 & -7.6551 & -7.333 & 8 & 0.000 \\
\hline \multicolumn{9}{|l|}{ Piped water } \\
\hline Pair 1 I-II & -5.3111 & 4.6131 & 1.5377 & -8.8571 & -1.7651 & -3.454 & 8 & 0.009 \\
\hline Pair 2 I-III & -13.6222 & 5.7389 & 1.9130 & -18.0335 & -9.2109 & -7.121 & 8 & 0.000 \\
\hline Pair 3 I-IV & -26.0333 & 7.2667 & 2.4222 & -31.6190 & -20.4476 & -10.748 & 8 & 0.000 \\
\hline Pair 4 II-III & -8.3111 & 3.4079 & 1.1360 & -10.9306 & -5.6916 & -7.316 & 8 & 0.000 \\
\hline Pair 5 III-IV & -12.4111 & 3.3928 & 1.1309 & -15.0191 & -9.8032 & -10.974 & 8 & 0.000 \\
\hline \multicolumn{9}{|l|}{ Electricity } \\
\hline Pair 1 I-II & -2.8889 & 2.1357 & 0.7119 & -4.5305 & -1.2473 & -4.058 & 8 & 0.004 \\
\hline Pair 2 I-III & -4.3778 & 2.7220 & 0.9073 & -6.4701 & -2.2854 & -4.825 & 8 & 0.001 \\
\hline Pair 3 I-IV & -5.3333 & 3.1599 & 1.0533 & -7.7623 & -2.9044 & -5.063 & 8 & 0.001 \\
\hline Pair 4 II-III & -1.4889 & 0.9842 & 0.3281 & -2.2454 & -0.7324 & -4.538 & 8 & 0.002 \\
\hline Pair 5 III-IV & -0.9556 & 0.8079 & 0.2693 & -1.5766 & -0.3345 & -3.548 & 8 & 0.008 \\
\hline
\end{tabular}

\section{References}

CONAPO (2000). Indice de marginación. Mexico: Secretaria de Gobernación.

De Soto, H. (1989). The other path: The invisible revolution in the third world. New York: Harper \& Row (Translated by June Abbott).

Duhau, E. (1998). Habitat Popular y Política Urbana. Azcapotzalco, Miguel Angel Porrua, México: Universidad Autónoma Metropolitana.

Ehrenberg, R. G., \& Smith, R. (2000). Modern labor economics. New York: Harper Collins College Publishers.

Guillén, T. (1990). Servicios Públicos y Marginalidad Social en la Frontera Norte. Frontera Norte, July-December 1990, México, Vol. 2(4), pp. 95-119.

Guillén, T. (2000). La Política Social y Los Municipios: una lectura fronteriza del norte de México. In R. Cordera, \& A. Zicardi (Eds.), Las Politicas Sociales de México al fin del Milenio: Descentralización, Diseño y Gestion (pp. 739-750). México: Instituto de Investigaciones Sociales-UNAM \& Miguel Angel Porrua.

Heikkila, E. J. (2000). The economics of planning. New Brunswick, NJ: Center for Urban Policy Research, Rutgers. 
Holcombe, R. (1983). Public finance and the political process. Champaign: Southern Illinois University Press.

Holcombe, R. (1996). Public finance: Government revenue and expenditures in the United States economy (1st ed). St. Paul, MN: West Publishing Co.

Levy, J. M. (1995). Essential microeconomics for public policy analysis. Westport, CT: Praeger.

Llera, F. (2003). El Paso del Norte Region: Who governs the urban planning process? In: C. Fuentes, \& S. Peña (Eds.), Planeación Binacional y Cooperación Transfronteriza en la Frontera Mexico-Estado Unidos. Mexico: El Colegio de la Frontera Norte \& Universidad Autónoma de Ciudad Juárez, in press.

Lorey, D. E. (Ed.) (1990). United States-Mexico border statistics since 1900. Los Angeles, CA: UCLA Latin American Center Publications.

Lorey, D. E. (Ed.) (1993). United States-Mexico border statistics since 1900: 1990 update. Los Angeles, CA: UCLA Latin American Center Publications.

Massolo, A. (1995). La Triste y Candida Historia de la Reforma Municipal. Ciudades, 28, 25-38 Red Nacional de Investigación Urbana.

Mendez, S. (1995). Municipio y Gestión Ambiental: El gobierno del PRD en Pátzcuaro (1990-1992). In A. Zicardi (Ed.), La Tarea de Gobernar: Gobiernos Locales y Demandas Ciudadanas (pp. 167-198). México: Instituto de Investigaciones Sociales-UNAM \& Miguel Angel Porrua.

Montesillos-Cedillo, J. (2000). Los Municipios y los organismos operadores en México: Una forma alternativa de financiar el saneamiento de agua potable. Federalismo y Desarrollo, 68, 120-130 México.

Ostrom, E., Schroeder, L., \& Wynne, S. (1993). Institutional incentives and sustainable development: Infrastructure policies in perspective. Boulder, CO: Westview Press.

Padilla, H. (1995). Ciudad Juárez: Administración pública y conflicto político en la experiencia de un gobierno panista. In A. Zicardi (Ed.), La Tarea de Gobernar: Gobiernos Locales y Demandas Ciudadanas (pp. 129-166). México: Instituto de Investigaciones Sociales-UNAM \& Miguel Angel Porrua.

Peach, J., \& Williams, J. (2000). Population and economic dynamics on the US-Mexican border: Past, present, and future. In P. Ganster (Ed.), SCERP monograph series 1 (pp. 37-72). San Diego: San Diego State University.

Peña, S. (2002). Land use planning on the US-Mexico border: A comparison of the legal framework. Journal of Borderlands Studies, 17(1), 1-20.

Peña, S., \& Córdova, G. (2001). Public participation and water supply: The case of two communities on the USAMexico border. Water International INWRA, 26(3), 390-399.

Pencavel, J. (1986). Labor supply of men: A survey. In: O. Ashenfelter, P. R. G. Layard, \& Richard Layard (Eds.), Handbook of labor economics, vol. 1. Amsterdam: North-Holland.

Pick, J., \& Butler, E. W. (1990). Socioeconomic inequality in the US-Mexico borderlands. Frontera Norte. Enero-Junio, 2(3), 31-62.

Serageldin, I. (1994). Water supply, sanitation, and environmental sustainability: The financing change. Washington, DC: The World Bank, Directions in Development.

Sim, L. L. S., Sau-Kim, L., \& Lai-Choe, M. L. (2002). "Property rights, collective sales and government intervention: Averting a tragedy of the anticommons. Habitat International, 26(4), 457-470.

Treviño, A. H. (1999). Actores y Organizaciones por el Agua. In: Ciudades: Actores Sociales, Poder Local, y Gestion del Agua. Red Nacional de Investigacion Urbana, \#43, Julio-Septiembre, Mexico.

Ward, P. (1991). Mexico una megaciudad: Producción y reproducción del medio ambiente urbano. Alianza: CONACULTA.

World Bank, (1997). The state in a changing world. World Development Report. Washington, DC, USA: World Bank.

\section{Further reading}

Border Environment Cooperation Commission, http://www.cocef.org/englishbecc.html.

Consejo Nacional de Población. índice de Desarrollo Humano Urbano Municipal (2000). http://www.conapo.gob.mx.

Constitución Política de los Estados Unidos Mexicanos, http://www.georgetown.edu/pdba/Constitutions/Mexico/ mexico1917.html.

Instituto Nacional de Geografía y Estadística (INEGI), (2000). XII Censo General de Población y Vivienda, http:// www.inegi.gob.mx. 